\title{
THE EFFECT OF RENAL DENERVATION ON PATIENTS SUFFERING FROM NEPHRITIS ${ }^{1}$
}

\author{
By IRVINE H. PAGE AND GEORGE J. HEUER
}

(From the Hospital of The Rockefeller Institute for Medical Research, and The Surgical Department of the Nere York Hospital and Cornell Medical College, New York City)

(Received for publication February 27, 1935)

Jaboulay (1) appears to have been the first to perform the operation of periarterial neurectomy in man. The procedure, however, did not achieve popularity until after the appearance of a series of papers by Leriche and his associates $(2,3)$. The effect on patients suffering from peripheral vascular disease has been especially extensively investigated. Denervation of the kidneys more recently has been performed on patients suffering from nephralgia and hydronephrosis, success being achieved in the relief of pain.

\section{ANATOMICAL}

The renal nerve supply is derived mainly from the celiac ganglia with small branches from the plexuses around the adrenal gland and the aorta. Usually one branch comes from the splanchnic nerves direct. Through the celiac ganglion the renal nerves are brought into connection with the splanchnic nerves and with the vagus. The vagus nerve also sometimes sends a direct branch to the kidneys. A few branches are received from the superior mesenteric ganglion.

It has long been recognized that the splanchnic nerves form the chief vasomotor supply of the kidneys. Bradford (4) found that stimulation of the anterior roots of the cord from the sixth thoracic to the second lumbar segment caused the kidneys to constrict. Of these roots the tenth to twelfth dorsal were most effective. Vasodilator fibers were also present but were weak in comparison with the constrictors.

Langley and Anderson (5), Jost (6), and Hirt (7) have clearly demonstrated fibers coursing from the third, fourth, and fifth lumbar ganglia to join the renal plexus. Most of the nerves are non-medullated, but some in the plexus are myelinated (Renner (8)). Ganglion cells which are

1 Delivered at the International Medical Assembly, Interstate Postgraduate Medical Association of North America, Philadelphia, November 8, 1934. numerous within the plexus are not found in the renal parenchyma.

Smirnow (9) observed that the nerves follow the blood vessels into the renal tissue even to the smaller capillaries. Motor nerve endings were seen in the smooth muscle of the vessels, as well as small nerve fibers in the capillary tuft of the glomeruli, the glomerular membrane and in the tubules. Sensory nerve endings occurred in the smooth muscle of the pelvis and in the connective tissue of the adventitia and media of most renal vessels and the capsules. Secretory nerves to the kidneys have never been convincingly demonstrated (Cushny (10)).

\section{PHYSIOLOGICAL}

Section of the splanchnic nerves in animals was shown by Claude Bernard (11) to be followed by increased excretion of urine more dilute than normal. This observation has been confirmed many times (Eckhard (12), Klecki (13) Grek (14), Rohde and Ellinger (15), Asher and Pearce (16), Jungmann and Meyer (17)). It also increases markedly the elimination of chlorides and carbonates and to a less extent that of urea, phosphates and sulfates. Elimination of creatinine, ammonia and phenolsulfonphthalein is unchanged according to Marshall and Crane (18). Section of the splanchnic nerves in frogs causes more glomeruli to fill with blood than in the control kidney (Bieter (19)). Should polyuria, increased blood flow and increased excretion of salt and urea, occur following denervation of the kidneys in patients, it would be of benefit.

Burton-Opitz and Lucas (20) showed that the vasoconstriction following stimulation of the splanchnic nerves or renal plexus occurs only on the side stimulated. Complete section of the renal nerves in animals was probably first performed by Carrel and Guthrie $(21,22)$. They were able to transplant both kidneys from one 


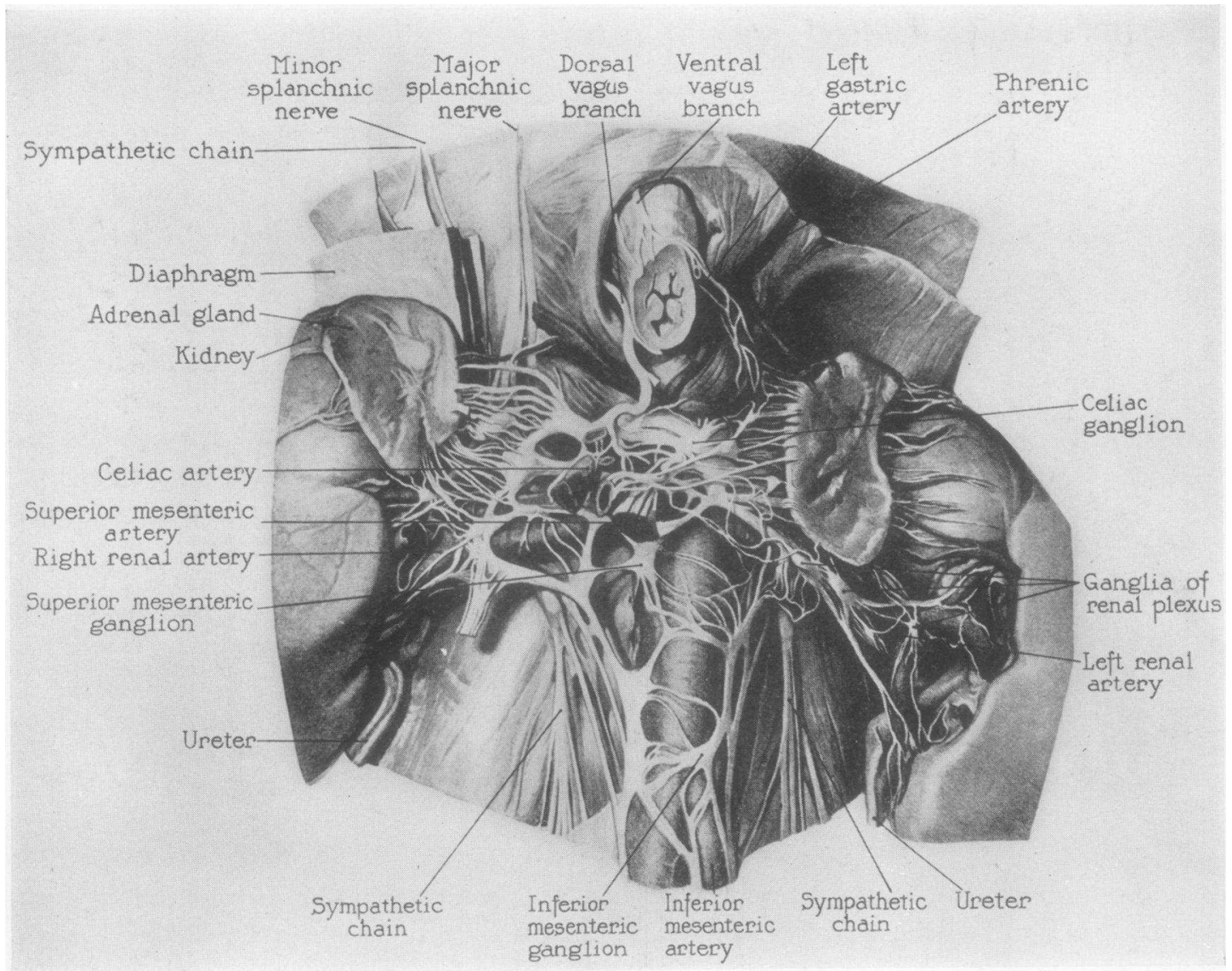

Fig. 1. Renal Nerves in Man.

From A. Hirt, Ztschr. f. Anat. u. Entwichung Gesch., 1924, 73, 621.

dog to another after having removed both kidneys from the latter. Except for some protein, the urine excreted was normal. 'This work was confirmed by Dederer (23, 24), Ibuka (25), and Holloway (26), who further showed that homeotransplants function adequately for some time.

Lobenhoffer (27) found that transplanted kidneys remain histologically normal at least for a few weeks, nor was there any difference in transplanted and normal kidneys in their ability to excrete water and sodium chloricle. Diuresis induced by hydremia showed that vascular efficiency was maintained.

Animals in which total hypophysectomy followed by decerebration had been performed did not exhibit increased flow of urine or any marked change in the output of chloride (Fee (28)). Denervation of the kidneys, however, resulted in the production of large amounts of hypotonic urine. Administration of pituitrin reduced the increased output to normal. Bayliss and Fee (29) found that perfusing innervated kidneys with heart-lung preparations, unlike isolated perfused kidneys, did not excrete large amounts of hypotonic urine until denervation was effected.

Renal denervation, just as splanchnic section in normal dogs, results in diuresis which may persist for months (Rohde and Ellinger (15), Stierlin and Verriotis (30), Caldwell, Marx, and Rowntree (31)), or not more than two weeks (Quinby (32)). The total amount of water, chloricles and urea eliminated was greater on the denervated side, and with little change in the amount of creatinine and phenolsulfonphthalein (Marshall and Kolls (33), Milliken and Karr (34), Kusakari (35)).

Hecht's experiment (36), in which oil was injected into the aorta after tying the vessel distal 
to the renal arteries, showed that more oil entered the vessels of the denervated than the normal kidney. Milles, Müller and Petersen (37) also found by $\mathrm{x}$-ray examination of injected kidneys that denervation caused chronic vasodilatation.

Quinby (32) tested the response of denervated kidneys to intravenous injection of hypertonic solutions of sodium chloride, urea and caffeine, and found that the reactions were practically identical with those of normal kidneys.

Rhoads, Van Slyke, Hiller, and Alving (38) have shown that infiltration with novocaine or section of the renal nerves in dogs was without consistent effect on either the excretory efficiency of the kidney, as measured by the urea clearance, or on the renal blood flow. There appeared, nevertheless, to be a possibility that the renal blood flow, and with it the function, might be increased in nephritic patients by denervation.

Müller and Petersen (39) observed that denervation prevented infection of kidneys by colon bacilli infused intravenously. X-ray photographs taken after injection of an opaque medium showed that dilatation of the larger arteries had occurred on the denervated side. Chilling animals caused constriction of the renal vessels in the innervated but not in the denervated kidneys. (Milles, Müller, and Petersen (40)). If the chilling was repeated daily, morbid changes occurred in the vascular bed of normal kidneys, conversely denervated kidneys remained unaltered. Clinical observation has implicated chilling of the skin as an important cause in the initiation of nephritis and in the appearance of exacerbations. Physiological evidence indicates that the caliber of the vessels of the kidneys follows closely that of the skin vessels (Cohnheim and Roy (41), Wertheimer (42)). Denervation in patients might dissociate these functions as it does in animals.

Hecht (43) found that suspensions of clumped. attenuated Staphylococcus aureus injected into the veins of rabbits caused more micotic abscesses to develop in normal than in denervated kidneys. If denervated kidneys are less susceptible to infection than are normal ones, denervation might be of therapeutic value in some conditions.

Normal kidneys excrete intravenously injected Bacillus prodigiosus in a wave-like fashion. Following denervation the number excreted was greatly reduced and the excretion became continuous (Milles and Nedzel (44)). It is possible that intermittency of excretion was due to periodic activity of the glomeruli (Richards and Schmidt (45)).

Kidneys of dogs following injection of colon bacilli, were not apparently injured for a period of about 30 minutes but, with the onset of chills, albumin, red blood cells and bacteria appeared in the urine (Müller, Petersen and Rieder (46)). If one kidney had been denervated, it continued to excrete normal urine after the injection of bacteria in spite of chills. Moriconi (47) was unable to prevent the appearance of suppurative nephritis in dogs by decapsulation and denervation.

It has been a favored theory that arterial hypertension in nephritis is due to nervous reflexes originating in the kidneys. Experiments performed on dogs by Page (48), in which renal hypertension had been produced by constricting the renal artery (Goldblatt, Lynch, Hanzal and Summerville (49)), did not support this view. He showed that hypertension resulted even when the nerve supply to the kidneys was severed. It was considered important to ascertain in patients whether the renal nerves were concerned in the genesis of nephritic hypertension.

\section{PREVIOUS CLINICAL DATA}

Temporary partial denervation of the kidneys has been attempted by means of paravertebral injections of local anesthetics. Wiedhopf (50) found that blocking the 11th and 12th dorsal and the first lumbar segments in patients produced an increase in urine and sodium chloride excretion, but Lurz and Röhrich (51) were unable to confirm this. Three cases of reflex anuria were thought by Haslinger (52) to be benefited by paravertebral injections of novocain. Splanchnic anesthesia also has its advocates in the treatment of reflex anuria (Neuwirt (53), Havlicek (54)).

Renal denervation in man was probably first performed by Papin (55) and by Legueu and Flandrin (56) for relief of pain in the kidneys. Since that time a number of urologists have performed the operation for nephralgia and painful conditions arising from contractions of the renal pelvis (Harris and Harris (5\%), Herbst (58), Hess (59), Stone (60)). Milliken and Karr 
(34) and Hess (59) from theoretical considerations gave the following indications for renal denervation:

1. Nephralgia, with or without accompanying non-obstructive hydronephrosis.

2. Unilateral hematuria without evidence of renal pathology.

3. As an adjunct to the removal of stones in the pelvis, with the hope that denervation may prevent subsequent recurrence.

4. Anuria that lasts longer than a few hours.

5. Early tuberculosis.

Rieder (61) has reported the results of unilateral denervation in the case of a patient suffering from what appeared to be early malignant sclerosis. The blood pressure was $240 / 110 \mathrm{~mm}$. $\mathrm{Hg}$, the nonprotein nitrogen $52 \mathrm{mgm}$, and the urine contained red blood cells and albumin. There were no eye-ground changes. Nine months after operation the blood pressure was $140 / 90$ $\mathrm{mm} . \mathrm{Hg}$, and the nonprotein nitrogen in the blood was normal. The urine excreted from the denervated kidney was less concentrated than that from the other kidney. Subjectively the patient was much improved.

If, as Volhard (62) believes, nephritis is caused by spasm of the vessels within the kidneys, provided the spasm is maintained by the nerves to the vessels, denervation should relieve it and increase the blood flow. General experience with the operation of denervation indicates that interruption of the nerve supply to vessels which are spastic restores normal tone, but that denervation of vessels with normal tone has little effect.

Page and Heuer (63) have shown that denervation of the kidneys in a patient with essential hypertension did not change the renal efficiency as measured by the urea clearance nor did it significantly reduce the ability to concentrate urine. Measurements performed before the operation indicated that renal function was normal.

\section{Selection of patients for operation}

Our intention was to select patients in whom nephritis had become chronic and progressed so far that, on the basis of previous observations (Van Slyke, Stillman, ct al. (64)), further progress to the terminal stage appeared certain unless corrected by therapeutic means. In order to avoid too great hazard in the operation, however, cases were chosen in which the urea clearance was still well above the 20 per cent level, which marks entrance into the terminal stage. The onset of the nephritis had occurred 16 months before operation in the earliest case and 26 months in the latest. Evidence of the clinical condition is given by the graphic charts.

\section{METHODS OF STLDY}

The patients were studied in the hospital several months before operation was performed. Reliance for studies of renal efficiency was placed on the urea clearance test of M $\phi 1$ ler, McIntoshl, and Van Slyke (65), not only because it is the most delicate test, but because Van Slyke, Rhoads, Hiller and Alving (66) have shown that in dogs it parallels the renal blood flow. The ability of the kidneys to concentrate urine was ascertained by the technique of Addis and Shevky (67), in which one measures the specific gravity of a 12-hour specimen of urine passed during the latter half of a 24-hour period, during which the patient received no fluids. A Westphal balance, modified by Alving and Van Slyke (68), was employed for the determination. Correction was made, as described by Lashmet and Newburgh (69), for the gravity contributed by the protein present in the urine. The figures thus represent nonprotein specific gravity of maximum concentration. Urinary protein was estimated by the Sherky-Stafford method (70). Red blood cells and casts were counted according to the technique of Addis (71). The hemoglobin of the blood was recorded in terms of volumes per cent of oxygen capacity. Plasma proteins were ascertained by the method of Howe (72). Plasma lipids were measured by the method of Kirk, Page and Van Slyke (73). Blood pressure measurements were made at about 9:30 a.m. with the patient in bed. On the charts these measurements for each week are averaged for convenience in representing them. Changes in the eyegrounds are recorded as follows: (1) constriction of the arterioles, (2) arteriolosclerosis, (3) exudate, (4) hemorrhages, (5) papilledema. The estimated time elapsing between onset of the disease and admission to the hospital is recorded in the lowest line on the charts, as the first number following the word "months." Diets were for the most part relatively high in protein and constant in caloric intake. They were supplied by a diet kitchen. ${ }^{1}$

\section{Operatize procedure}

The technique of bilateral renal denervation as we have performed it may briefly be described as follows: Under general anesthesia the usual kidney incision is made upon the right side, the perirenal fat separated, and the kidney exposed. With great care, in order to avoid bleeding,

1 We wish to thank Miss G. Drew for her skilful management of the diets. 


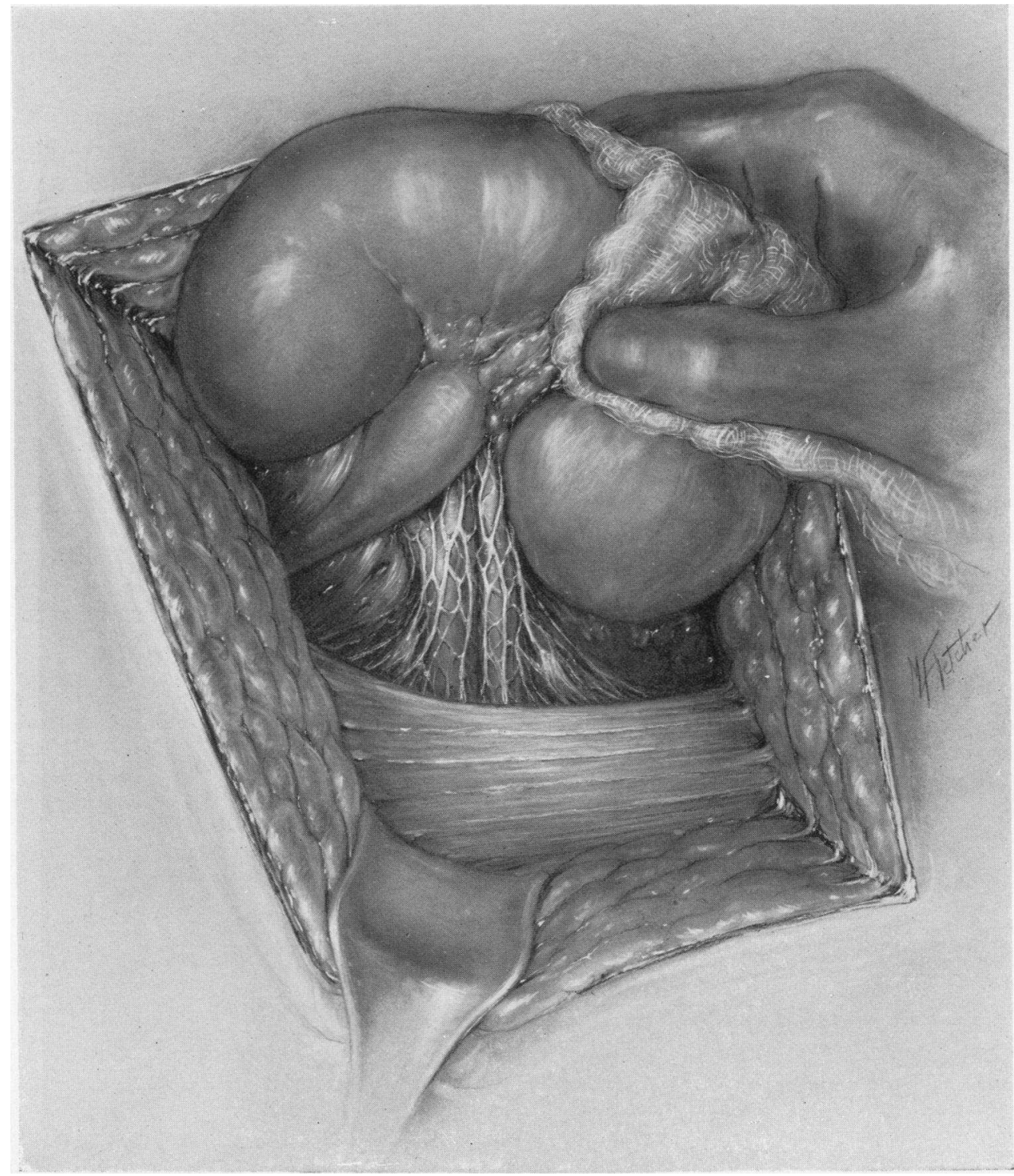

Fig. 2. Operative Exposure of the Kidney Showing the Nerves of the Renal Pedicle.

the fat is stripped away from the kidney, which is gradually completely freed and drawn well outside of the body. The ureter, renal artery, and vein having been identified, the renal vessels are stripped of all fat downward to their point of origin. If the freeing of the vessels is meticulously performed, the operator then will plainly see the sympathetic nerves coursing from their origin to the kidney. They appear as a fan-shaped, triangular mass upon both the dorsal and ventral aspects of the renal vessels, the base of the triangle being directed toward the aorta and vena cava, the apex converging upon the renal vessels. Upon reaching the renal vessels, the nerves apply themselves more closely to them and surround them in a more or less well defined basket weave plexus.
The nerves having been identified their excision is begun. Beginning upon the ventral aspect of the vessels exposed by drawing the kidney backward, the fan-shaped mass of nerves is carefully freed and divided near the vena cava. The mass is grasped, drawn upward and outward, and the nerves stripped from the artery and vein up to their entrance into the kidney. Having completed the removal of the nerves from the ventral aspect of the vessels, the kidney is drawn forward and a similar resection of the nerves upon the dorsal aspect of the vessels is performed. These two procedures remove practically all the nerves to the kidney; but there may remain a few which are applied to the opposing surfaces of the artery and vein. These vessels are therefore separated, and a search made for any remaining nerves. If found they 
are resected. At the completion of the operation the artery and vein should appear as naked, isolated structures completely stripped of all nerves. The kidney is then replaced in its fatty bed, and the wound closed. Two weeks to a month or more later a similar operation is carried out upon the opposite side.

The operation has been well borne both during and after the procedure. Neither the renal artery or vein has been injured in any patient thus far subjected to operation, nor has there been a single incident to mar the postoperative convalescence. Experience has shown that adequate exposure is of the greatest importance in the performance of the operation, and we have, therefore, when operating upon the left side, unhesitatingly divided the twelfth or the twelfth and eleventh ribs in order to secure it.

\section{PROTOCOLS}

Case 1. (See Figure 3.) Hospital Number 8333, (E.McG.), female, age 57 years. The onset of the disease was insidious in character seven months before admission to the hospital. She complained of severe headaches, nausea and scanty passage of urine. Dr. E. Mayne found hematuria, albuminuria, edema, and the blood pressure elevated to $210 \mathrm{~mm}$. of $\mathrm{Hg}$. Rest and a low protein, low salt diet did not improve her condition, and as she appeared to be raipdly getting worse she was referred to the hospital by Dr. Mayne. Edema had been especially severe and troublesome.

The physical examination disclosed that the eyegrounds were normal except for a small fresh hemorrhage in the right retina. The heart was very slightly enlarged. The radial vessels were thickened and slightly tortuous. Pitting edema was observed up to the knees. Blood pressure was 198/104 mm. of Hg. Inhalation of amyl nitrite caused it to fall $58 \mathrm{~mm}$. of $\mathrm{Hg}$ systolic and $40 \mathrm{~mm}$. diastolic. The electrocardiogram showed all the $T$ waves positive, conduction time 0.16 seconds, moderate left ventricular preponderance.

Twenty-three months after the onset of the disease it was clear that the urea clearance was stabilized at about 50 per cent of normal and that maximum concentrating ability was 1.020 . The hemoglobin rose to normal and hematuria disappeared. Total plasma protein also approached normal, but the albumin fraction remained at 3 per cent. Excretion of protein in the urine fluctuated little from 5 grams in 24 hours. The blood pressure varied from 160 to $200 \mathrm{~mm}$. of $\mathrm{Hg}$ systolic and 80 to $110 \mathrm{~mm}$. diastolic.

Right renal denervation was performed March 3, 1934, during the 24th month of the disease. The kidney was bound down by many dense adhesions but was found to be of normal size. It was moderately scarred, and the renal arteries were smaller than normal, were beaded, and showed definite sclerosis. The masses of nerves removed showed on section that the majority were nonmyelinated, but a few myelinated nerves were present. The postoperative course was uneventful, and at no time

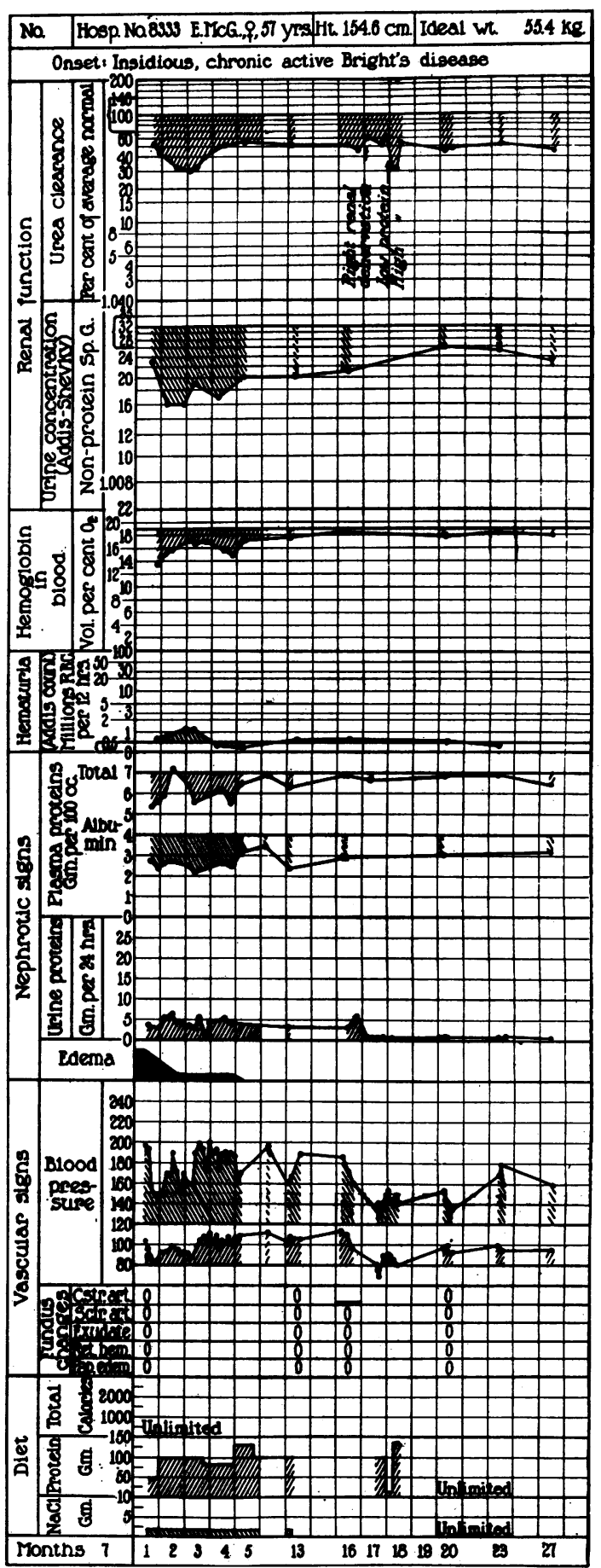

Fig. 3. Unilateral Denervation in Patient with Chronic Active Nephritis.

did oliguria develop. The urea clearance test performed 18 days after operation showed that it had improved slightly. About three months later cystoscopy was done by Dr. O. Lowsley, and the urea clearance was per- 
formed on specimens from the catheterized ureters. The results were as follows:

\begin{tabular}{l|c|c|c|c|c}
\hline \hline & Time & $\begin{array}{c}\text { Cor- } \\
\text { rected } \\
\text { urine } \\
\text { volume } \\
\text { per } \\
\text { minute }\end{array}$ & $\begin{array}{c}\text { Urea } \\
\text { N }\end{array}$ & $\begin{array}{c}\text { Blood } \\
\text { urea N }\end{array}$ & $\begin{array}{c}\text { Clear- } \\
\text { ance } \\
\text { in per } \\
\text { cent of } \\
\text { nor- } \\
\text { mal }\end{array}$ \\
\hline & & & mgm. & mgm. & \\
Denervated kidney ... & 30 & .62 & 580.0 & 23.49 & 36.2 \\
Control kidney ....... & 30 & .59 & 528.0 & & 31.9 \\
\hline
\end{tabular}

Six months after operation the urea clearance had not changed from the preoperative level. Ability to concentrate urine rose from 1.020 maximum nonprotein specific gravity to 1.027 . The protein excretion in the urine fell sharply to less than one gram in 24 hours. The blood pressure fell and remained at almost $150 / 90 \mathrm{~mm}$. of $\mathrm{Hg}$, but has shown a definite tendency to return to the preoperative level. Subjectively the patient feels much improved and has returned to her household and social activities. We have not urged the denervation of the left kidney.

Case 2. (See Figure 4.) Hospital Number 8634. (E.G.) female, aged 22 years. The onset of the disease was acute three months before admission to the hospital. She suffered from a severe sore throat and two weeks after its onset woke up one morning to find edema of her face, hands and feet. Two days later ascites developed. Hematuria and albuminuria were found, and the blood pressure was $150 / 90 \mathrm{~mm}$. of $\mathrm{Hg}$. The patient began to vomit and suffered from severe headaches; consequently she was referred to this hospital by $\mathrm{Dr}$. $\mathrm{H}$. Greisman.

Physical examination disclosed marked edema of the legs and a small amount of fluid in the abdomen. In both eyegrounds there were numerous old and fresh hemorrhages. Anemia was very marked, and the blood pressure was $158 / 98 \mathrm{~mm}$. of $\mathrm{Hg}$. Gastric analysis showed that there was no free $\mathrm{HCl}$ in the fasting specimen and none 40 minutes after alcohol, but 33 after histamine. Total acid in the fasting specimen was 3.1, 11.4 after alcohol and 47.0 after histamine. The $\mathrm{pH}$ of the serum was 7.24, $\mathrm{CO}_{2} 17.29$ millimols per liter, chlorides 109 milli-equivalents, and total base 148.2 milli-equivalents per liter. Blood lipids were as follows: total fat 1896 mgm., total cholesterol 718 mgm., free cholesterol 194 mgm., ester cholesterol 524 mgm., lipid amino-nitrogen $12.5 \mathrm{mgm}$., lipid phosphorus $19.8 \mathrm{mgm}$., total lipid nitrogen $35.5 \mathrm{mgm}$. per $100 \mathrm{cc}$. of plasma.

One month after admission paravertebral anesthesia was administered by Dr. H. Wertheim at Dr. A. Alving's suggestion. Novocain was injected on both sides of the vertebrae from the ninth thoracic to the first lumbar segments. Two hours prior to the injection the clearance was 13.9 per cent of normal. Two hours after the anesthesia it was 15.2 per cent and 14.1 during the next two hours. Evidently paravertebral novocain anesthesia had no effect on the renal blood flow as measured by the urea clearance test.

During the next seven months, as shown by Figure 2, urea clearance and hemoglobin rose steadily. Thereafter, however, no further improvement occurred, and it became evident that the case had become chronic. The most concentrated urine the patient could excrete had a specific gravity of 1.012 , and there was only a slight increase associated with the rise in urea clearance. Other data are evident from the chart.

Right renal denervation was performed on May 23, 1934 , in the sixteenth month after the onset of the disease. The kidney was rather large and pale, measuring $12 \mathrm{~cm}$. in length, $6.5 \mathrm{~cm}$. in width at the pelvis and $4.5 \mathrm{~cm}$. in thickness. It was moderately scarred, but the main renal vessels were quite normal in appearance.

Twenty-one days after operation the patient was cystoscoped, and the urea clearance test was performed on the urine collected from the ureteral catheters.

\begin{tabular}{l|c|c|c|c|c}
\hline \hline & Time & $\begin{array}{c}\text { Cor- } \\
\text { rected } \\
\text { urine } \\
\text { volume } \\
\text { per } \\
\text { minute }\end{array}$ & $\begin{array}{c}\text { Urea } \\
\text { N }\end{array}$ & $\begin{array}{c}\text { Blood } \\
\text { urea N }\end{array}$ & $\begin{array}{c}\text { Clear- } \\
\text { ance } \\
\text { in per } \\
\text { cent of } \\
\text { nor- } \\
\text { mal }\end{array}$ \\
\hline & & & mgm. & mgm. & \\
Denervated kidney... & 30 & 0.77 & 417.0 & 32.8 & 21.1 \\
Control kidney..... & 30 & 0.58 & 438.0 & & 18.8 \\
\hline
\end{tabular}

Studies made during the next four months showed that unilateral denervation caused no significant change in the urea clearance, ability to concentrate urine or the hemoglobin. Hematuria markedly diminished, and plasma proteins rose very slightly. Excretion of protein in the urine diminished about 60 per cent. Changes in blood pressure level were not considered significant. The patient was edema-free even though salt was allowed in the diet. Determination of plasma lipids showed that a marked fall had occurred. Lipids in $100 \mathrm{cc}$. of plasma were: total fat $1220 \mathrm{mgm}$., total cholesterol $535 \mathrm{mgm}$., free cholesterol 238 mgm., ester cholesterol $297 \mathrm{mgm}$., lipid amino-nitrogen $4.6 \mathrm{mgm}$., lipid phosphorus 14.2 mgm. and total lipid nitrogen $17.3 \mathrm{mgm}$.

The left renal denervation was performed on October 2, 1934, about four months after the initial operation. The kidney was smaller than on the right, measuring $10.3 \times 5$ $\mathrm{x} 4 \mathrm{~cm}$. There appeared to be no evident change in the clinical or laboratory findings over those observed following the first operation.

Case 3. (See Figure 5.) Hospital Number 8860 . (J. S.), female, age 22 years. Two months before admission the patient noticed that her feet and ankles were swollen. One month before this she became pregnant. Four months later she was admitted to the Presbyterian hospital because of ascites. Excretion of urine had diminished, and she complained of palpitation, substernal oppression and transitory loss of vision. The Wasserman test was negative. Much protein and a few red blood cells were found in the urine. It was necessary to 


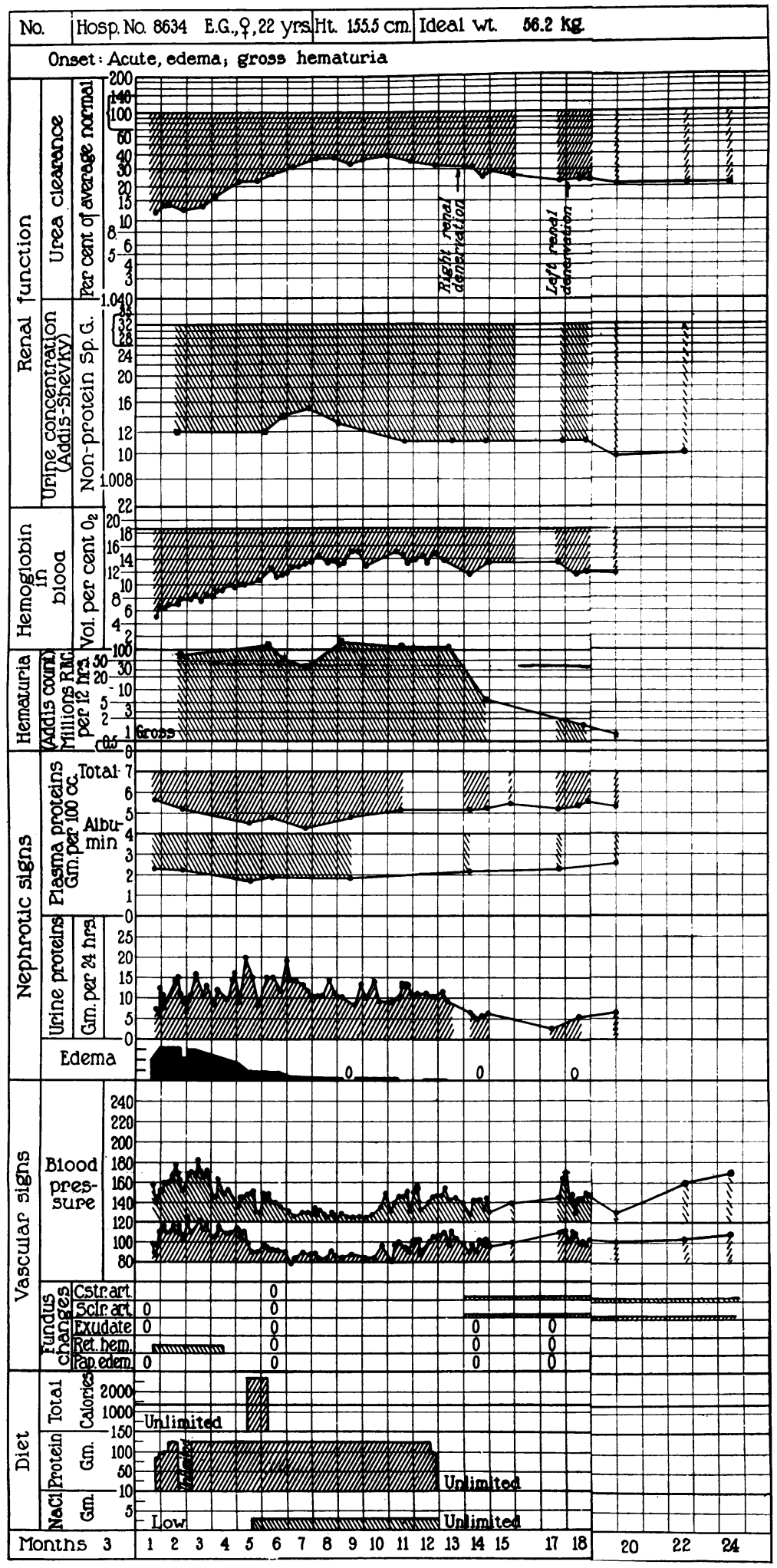

Fig. 4. Bilateral Denervation in Patient with Chronic Active Nephritis. 


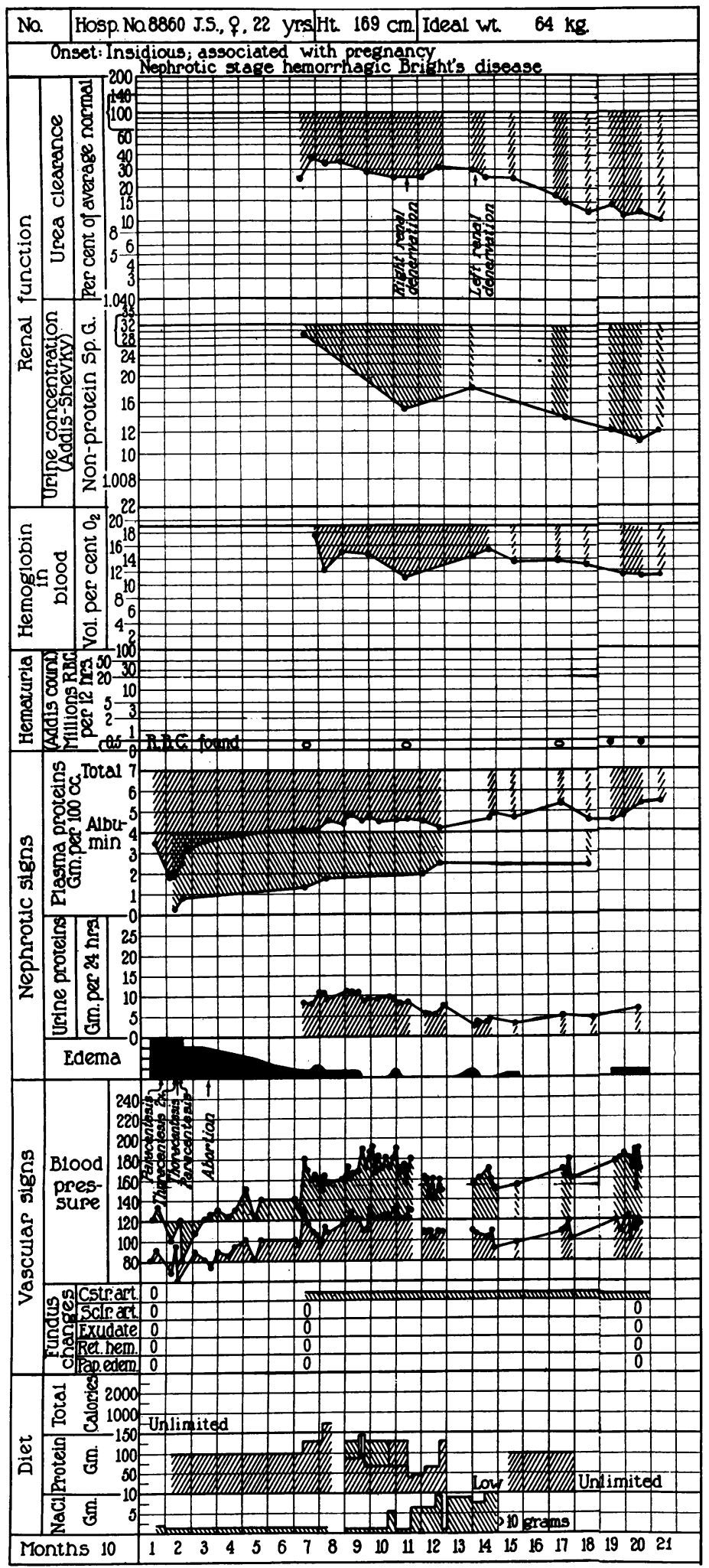

Fig. 5. Bilateral Denervation in Patient with Chronic Active Nephritis in the Nephrotic Stage. 
perform thoracentesis and paracentesis to remove some of the fluid. Intravenous injections of gum acacia were given without any beneficial effect being observed. Her basal metabolism was found to be -18 per cent. Colitis developed with diarrhea and bloody stools. Because of the patient's serious condition an abortion was performed. About one month later phlebitis of the left arm appeared, which healed with conservative treatment. A week later the patient was sterilized by resection of the tubes. The right kidney was seen to be much enlarged, while the left was about normal in size. Three months later she was discharged from the hospital but returned in two days because severe edema immediately developed. Her basal metabolism was then -24 per cent. We are indebted to D)r. A. Harris and Dr. W. Anderton for this information.

Physical examination disclosed marked anemia, edema and malnutrition. The eyegrounds were normal except for beginning arteriosclero.is. Blood pressure was elevated to $180 / 130 \mathrm{~mm}$. of $\mathrm{Hg}$.

The electrocardiogram showed the $\mathrm{T}$ waves to be negative in Leads $I$ and $I I$. Conduction time was $0.16, R_{3}$ and $\mathrm{S}_{3}$ were split, and left ventricular preponderance was present. Renal efficiency was markedly impaired. The first examination indicated that she had retained power to concentrate urine, but four months later the maximum nonprotein specific gravity of the urine was 1.015. Marked anemia was found, and the plasma proteins were reduced to well below the level at which nephrotic edema appears. Excretion of protein in the urine averaged about 10 grams in 24 hours.

The patient was fed a high protein, low salt diet. A small rise in plasma protein occurred, and much of the edema slowly subsided. The renal efficiency, however, appeared to be gradually diminishing, and during four months marked loss of ability to concentrate urine occurred. Blood pressure also increased.

Right renal denervation was performed on April 18 . 1934 , in the 21 st month after onset of the disease. The kidney was congested, hyperemic and large. measuring $12.5 \times 7 \times 4.5 \mathrm{~cm}$. in length, breadth and thickness. The main arteries appeared constricted.

The urea clearance and ability to concentrate urine rose slightly after the operation. Hemoglobin and plasma proteins also were increased, and excretion of protein in the urine diminished by about 50 per cent. No significant change in blood pressure occurred.

()n July 6, 1934, about seven weeks after the first operation, denervation of the left kidney was performed. Again this kidney was found to be large, lobulated and perhaps somewhat pale. It measured $11.5 \times 6 \times 5 \mathrm{~cm}$. in its various diameters. Directly following this operation no significant change was observed in the clearance, hemoglobin, blood pressure or urinary protein excretion. The patient was discharged from the hospital and lived in surroundings very adverse to her health. She drank rather heavily and was unable to take any care with her diet. She suffered from a series of colds. Examinations made at intervals showed that the renal function was gradually being lost. Plasma proteins have re- mained about 5 per cent, and the excretion of protein in the urine has continued at a reduced level.

Case 4 (See Figure 6). Hospital Number 8740 (G.

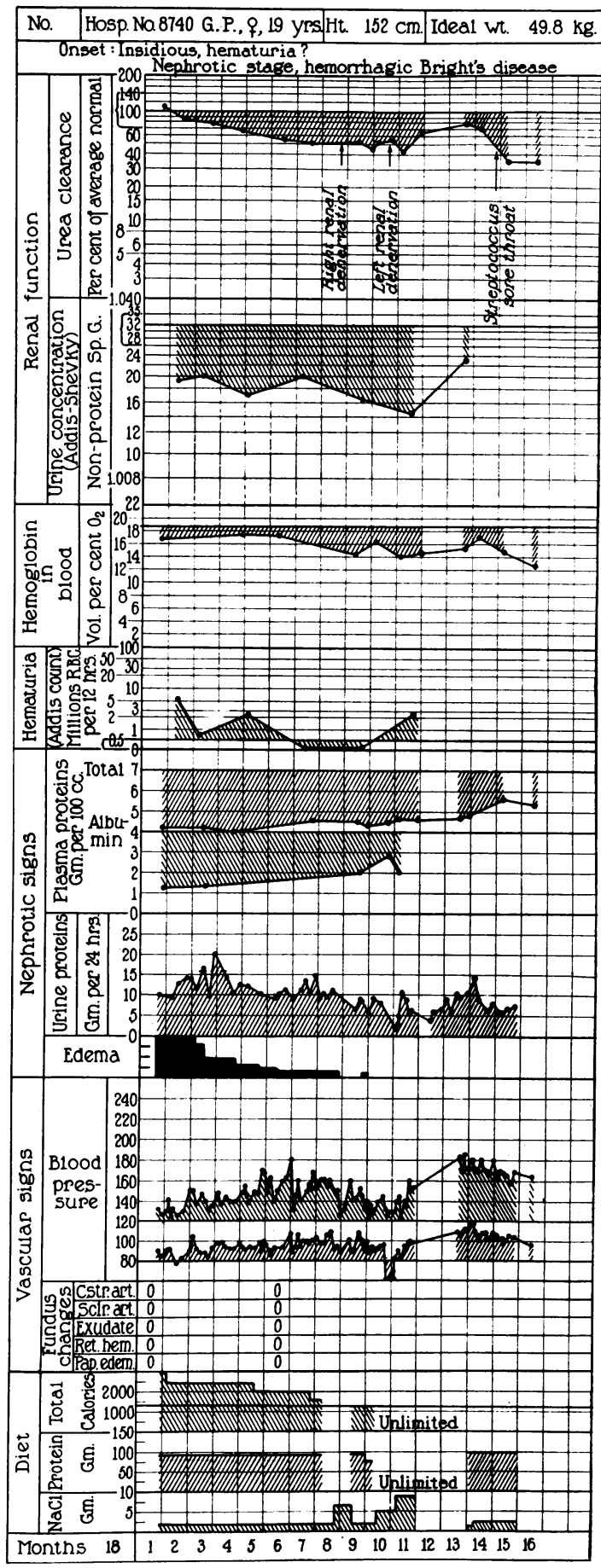

Fig. 6. Bilateral Denervation in Patient with Chronic Active Nephritis in the Nephrotic Stacie. 
P.), female, age 19 years. Eighteen months before admission she noticed gradually increasing swelling of her ankles. Albumin and red blood cells were found in her urine. After a short rest in bed she resumed her work. Edema reappeared and during the next eighteen months was almost constantly present.

Examination showed that she was very pale. Her face and legs were swollen with edema. Fluid was present in her chest and abdomen. Eyegrounds were normal. The blood pressure was $130 / 90 \mathrm{~mm}$. of $\mathrm{Hg}$.

The urea clearance was 103 per cent of normal on admission, but the maximum nonprotein specific gravity of the urine was 1.019 . Hemoglobin was moderately reduced, and about 5 million red blood cells were being excreted in 12 hours in the urine. Excretion of protein ranged from 10 to 20 grams in 24 hours. Plasma proteins were severely depleted to 4.09 per cent total protein, albumin 1.19 , globulin 2.90 , and $A / G$ ratio 0.41 . Serum chloride was 103.7 milli-equivalents per liter, and total base of serum 149.6 milli-equivalents per liter. Lipids in $100 \mathrm{cc}$. of plasma were as follows: total fat $2121 \mathrm{mgm}$., total cholesterol $589 \mathrm{mgm}$., free cholesterol $442 \mathrm{mgm}$., ester cholesterol $147 \mathrm{mgm}$., lipid amino-nitrogen 6.64 mgm., total lipid nitrogen 17.75 mgm., lipid phosphorus $11.65 \mathrm{mgm}$. Liver function was normal as measured by the rate of deaminization and urea formation by Kirk (74). The Wassermann test was negative.

Renal efficiency fell progressively even though she was confined to bed. Hematuria and proteinuria continued, and the blood pressure rose slowly, reaching a maximum of $180 \mathrm{~mm}$. systolic and $110 \mathrm{~mm}$. diastolic.

On April 26, 1934, twenty-six months after onset of the disease, denervation of the right kidney was performed. The kidney was large and pale and measured $12.5 \times 6.5 \times 5 \mathrm{~cm}$. in its various diameters.

Shortly before operation the urea clearance was 52.3 per cent of normal, and eighteen days after, was 54.0 per cent of normal. Edema which constantly had been present disappeared promptly following operation, although unrestricted amounts of salt were allowed instead of the previous low salt diet. No significant change occurred in her ability to concentrate urine. A slight fall in hemoglobin appeared, presumably due to the operation. No significant rise in plasma proteins occurred, although some diminution in proteinuria was observed.

Blood pressure fell somewhat. Clearance tests performed on the urine from the catheterized ureters showed that there was no significant difference in the clearance of the denervated as compared with the other kidney.

\begin{tabular}{l|c|c|c|c|c}
\hline \hline & Time & $\begin{array}{c}\text { Cor- } \\
\text { rected } \\
\text { urine } \\
\text { volume } \\
\text { per } \\
\text { minute }\end{array}$ & $\begin{array}{c}\text { Urea } \\
\text { Ne }\end{array}$ & $\begin{array}{c}\text { Blood } \\
\text { urea N }\end{array}$ & $\begin{array}{c}\text { Clear- } \\
\text { ance } \\
\text { in per } \\
\text { cent of } \\
\text { nor- } \\
\text { mal }\end{array}$ \\
\hline Denervated kidney ... & 30 & 1.75 & 121.8 & 17.09 & 17.5 \\
Control kidney ....... & 30 & 1.79 & 142.5 & & 20.6 \\
\hline
\end{tabular}

On June 18, 1934, about seven weeks after the first operation, denervation was performed on the left kidney. The kidney measured $13 \times 7 \times 5.8 \mathrm{~cm}$. in diameter. The exposure was difficult, and the operator was not satisfied with the completeness of the excision of the nerves about the renal artery.

The urea clearance rose after the second operation, reaching a maximum of 78 per cent of normal within three months. The ability to concentrate urine as measured by the nonprotein specific gravity rose from 1.014 to 1.023. Plasma proteins increased to a maximum of 5.7 per cent, and the protein in the urine decreased moderately. Blood pressure also increased somewhat, but appears now to be falling.

A very severe infection of the throat with hemolytic streptococcus apparently interrupted the trend toward increasing renal efficiency. Two months after operation lipids had diminished to the following values: total fat $1561 \mathrm{mgm}$., total cholesterol $442 \mathrm{mgm}$., lipid aminonitrogen 6.9 mgm., total lipid nitrogen 23.4 mgm., lipid phosphorus $17.4 \mathrm{mgm}$. per $100 \mathrm{cc}$. of plasma.

Case 5. (See Figure 7.) Hospital Number 8295. (D.M.), aged 9 years. Onset of the nephritis occurred four months before admission during the course of a febrile disease, probably scarlet fever. The child had no complaints except for almost continuous edema of the ankles and often of the face.

Physical examination showed that there was moderate edema of the face, sacral region and shins. The lymph glands of the left submaxillary region were enlarged and tender. Blood pressure was elevated to $148 / 72 \mathrm{~mm}$. Eyegrounds were normal. Many red blood cells and casts were found in the urine. It boiled almost solid with protein.

Hemolytic streptococci were grown from a culture taken from her throat. Two weeks later her temperature rose, and the cervical glands became acutely inflammed. Surgical drainage yielded pus from which hemolytic streptococci were grown. When this infection had cleared the hematuria rapidly subsided, but as many as $6,200,000$ casts, of which 80 per cent were hyaline and 18 per cent granular, were excreted in 12 hours. Doubly refractive globules were found.

The urea clearance was 53 per cent of normal, maximum nonprotein specific gravity 1.018 , and hemoglobin 13.4 volumes per cent oxygen capacity. The excretion of protein in the urine varied from 10 to $14 \mathrm{grams}$ in 24 hours.

Edema disappeared with rest in bed and a light diet moderately low in salt. After discharge from the hospital three months later, edema again appeared. She was seen nine months later. There was slight edema of the shins, blood pressure was higher, the heart was moderately enlarged, and the retinal arterioles appeared somewhat constricted. The urea clearance had fallen to 34 per cent of normal. Two weeks later lobar pneumonia Types X and XXIX developed. The temperature was normal two days after onset, but complete resolution did not occur until after seven weeks. Gross hematuria developed, and the clearance fell to 25 per cent of normal. 


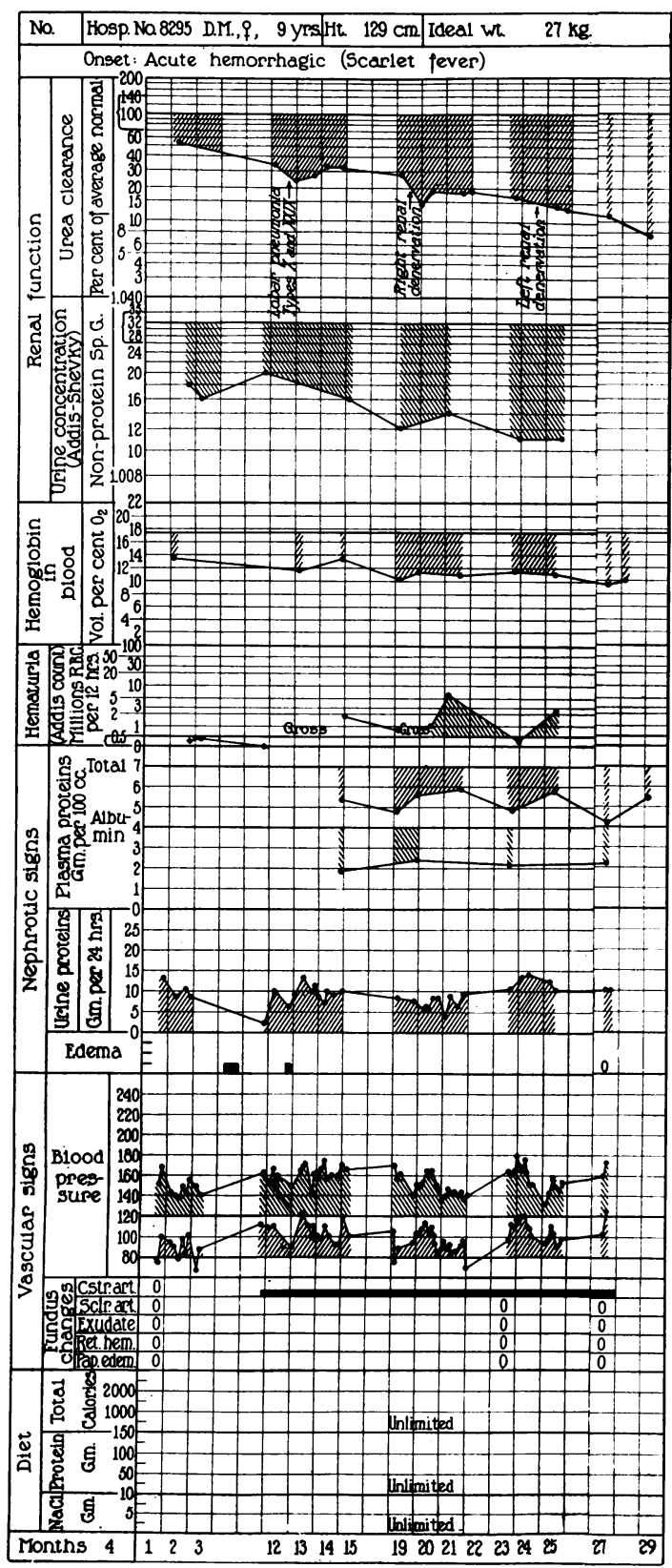

Fig. 7. Bilateral. Denervation in Patient with Chronic Active Nephritis.

One month after onset of pneumonia cardiac decompensation developed.

The prognosis appeared hopeless since the renal efficiency, as measured by the urea clearance and ability to concentrate urine, was steadily diminishing. Hemoglobin also fell progressively, and the blood pressure remained high.

On May 17, 1934, during the twenty-third month of the disease, right renal denervation was performed. The kidney was of the large white variety measuring $12 \times 6 \times$
$4.2 \mathrm{~cm}$. The renal vessels appeared of normal size and showed no evidence of sclerosis.

Following operation the clearance and hemoglobin continued to fall slowly. Plasma proteins rose sharply from 4.89 per cent to 5.65 per cent and finally to 5.95 per cent in two months. The blood pressure was not altered significantly. Five months later on October 22, 1934, left renal denervation was performed. The kidney in size and color resembled the right. During the three months of observation following, the clearance continued to fall, as well as the ability to concentrate. Proteinuria continued, and blood pressure remained elevated.

\section{Examination of blood a'essels of muscle}

At operation, specimens of lumbar muscle were removed for microscopic examination of blood vessels. Dr. C. P. Rhoads has given as his opinion that the vessels of only one patient (Number 2) exhibited definite evidence of intimal thickening. Case 5 also had slight morbid changes of the vessels; but the remaining patients showed no definite alteration.

\section{DISCLSSION}

Renal denervation had no immediate effect on renal efficiency, as measured by the urea clearance test. Van Slyke, Rhoads, Hiller and Alving (66) have found that in $\log s$ the urea clearance parallels chiefly the renal blood flow. If the same parallelism occurs in nephritic patients, failure to increase the clearance indicates failure to increase the renal blood flow. The observation that clearances performed on specimens collected from the ureter of the denervated and inervated kidney of the same patient are practically alike, demonstrates in a conclusive manner the non-effect of denervation on the urea clearance. Nor did the specimens from the two ureters show any effect of denervation on the urine volume. Over a period of months following operation, the clearances of four patients have shown no tendency to change in a way other than that which might have been anticipated from the previous trend. One case (Number 4) differed in that it rose one month after the last denervation.

Rhoads, Van Slyke, Hiller and Alving (38) found no change in the clearance following denervation of normal dog kidneys. Page and Heuer (63) showed that denervation of the kidneys of a patient suffering from essential hypertension did not alter the clearance. The kidneys of this patient were normally efficient as measured by the clearance and concentrating ability. 
Denervation caused neither increased urine flow nor diminished ability to concentrate, although animal experiments in the literature $(11,12,13$, $14,15,16,17,18)$ led us to expect these changes. On the contrary, two patients (Cases 1 and 4) exhibited a significant increase in concentrating power during the months after operation. In the remaining three cases a slow loss of this capacity occurred, parallel with reduction in the urea clearance. The loss in concentrating power was, however, no more rapid than is likely to occur during the usual progress of cases of this type (e.g., see charts of Cases 9 and 11 of Alving and Van Slyke (68)).

Excretion of red blood cells in the urine was sharply diminished in one case (Number 2), fa!ling from one hundred million cells to slightly more than one million in a concentrated 12 -hour specimen. It was uninfluenced in the other cases, in which excretion was already minimal. Excretion of protein was reduced in four of the five patients.

The most marked effect was observed in Case 1. Excretion of protein in the urine had been constantly at a level of 3 to 5 grams in 24 hours for a period of at least 16 months. Directly following unilateral denervation it fell to less than a gram and has remained so for 7 months. Proteinuria was diminished from an average level of 10 to 15 grams to 5 grams in Case 2, from 10 grams to 5 grams in Case 3 , from 12 grams to 8 grams in Case 4, and was uninfluenced in Case 5.

A rise in plasma protein might have been expected as a result of decreased excretion in the four cases cited above. It is, however, difficult to tell whether the operation affected the plasma protein level. In Case 4 a rise from a preoperative level of about 4.5 per cent of total protein to 5.5 per cent occurred, but not until four months after the second denervation. In Case 3 there may have been a similar rise. However, it is common for similar rises to occur spontaneously, especially when the urea clearance falls to about 20 per cent of normal (See Alving and Van Slyke, Cases 6 to $11(68))$. The most that one can say definitely is that denervation does not lower the plasma proteins, and may assist in raising them.

As a result, probably, of the increase in plasma proteins, edema disappeared in Case 4, in which it had been present before operation. Following the first denervation, it disappeared in a dramatic fashion, and, except for a slight recurrence for a period of a week, has not returned, in spite of the fact that salt was increased to 9 grams per day. Of the other patients, Numbers 1,2, and 5, were edema-free before operation and have remained so. Number 3 showed sporadic edema both before and after.

Plasma lipid concentration was studied in two cases (Numbers 2 and 4). Reduction in all fractions was observed following denervation. It is difficult, however, to be certain that this was not a spontaneous change.

Blood pressure fell in all of the cases and remained below preoperative level for from weeks to months following each operation. The fall was not permanent, however; in each case the pressure later returned to, or near to, its former level. Experiments performed by Page (48) on dogs, in which hypertension was produced by $\mathrm{x}$-ray irradiation of the kidneys or by constricting the renal arteries (49), showed that hypertension resulted in animals with their kidneys denervated as surely as in normal animals. There was, therefore, little reason to hope that denervation in patients would permanently reduce their blood pressure. Furthermore, it has been shown by Page (75) that renal efficiency, as measured by the clearance, is dissociated from the level of arterial blood pressure in patients with hypertension of the nephritic or essential variety. The probability may be assumed that renal blood flow also is not directly dependent on the level of arterial blood pressure.

From clinical observations of the weight and response of the patients to ingestion of water, we have no reason to believe that denervation alters the water balance of the body. It is reasonable, therefore, to assume that the extrinsic renal nerves do not control its water balance.

Our cases were selected from those in which the prognosis was bad and, further, those in which the morbid process had become chronic. Possibly if the operation were performed early in the course of the disease, more favorable results might be achieved. This is a matter on which we hope to report at a later date.

\section{CONCLUSIONS}

1. Renal denervation in patients with chronic nephritis caused excretion of protein to diminish 
in four out of five cases. Unilateral denervation may be as effective as the bilateral operation in this regard.

2. Renal efficiency, as measured by the urea clearance test, is not altered following unilateral or bilateral denervation. It appears probable, from this result, that denervation does not increase renal blood flow.

3. Decreased ability to concentrate urine did not occur, although from animal experiments in the literature it might have been anticipated. On the contrary, two of five patients exhibited increased concentrating power.

4. The level of blood pressure fell in all of the cases for a few weeks after operation, but in all but one case regained its original value. Failure of denervation to affect the blood pressure appears to be evidence against the theory that nervous impulses, originating in the kidneys and conducted by their extrinsic nerve supply, are responsible for the genesis of hypertension in patients with chronic nephritis.

\section{BIBLIOGRAPHY}

1. Jaboulay, M., La section du sympathique cervical dans ses effets sur la vision chez l'homme. Lyon méd., $1895,80,341$.

Sur un résultat éloigné de la sympathicotomie. Lyon méd., 1902, 99, 757.

2. Leriche, R., Sur l'étude expérimentele la technique et quelques indications nouvelles de la sympathectomie périartérielle. Presse méd., 1922, 30, 1105.

3. Leriche, R., and Heitz, J., Des effets physiologiques de la sympathectomie périphérique. Compt. rend. Soc. de biol., 1917, 80, 66.

4. Bradford, J. Rose., The innervation of the renal blood vessels. J. Physiol., 1889, 10, 358.

5. Langley, J. N., and Anderson, H. K., The innervation of the pelvic and adjoining viscera. J. Physiol., 1896, 20, 372.

6. Jost, W., Die Sympathische Innervation der Niere. Ztschr. f. Biol., 1914, 64, 441.

7. Hirt, A., Vergleichend-anatomische Untersuchungen über die Innervation der Niere. Ztschr. f. Anat. u. Entwcklngsgesch., 1924, 73, 621.

8. Renner, O., Über die Innervation der Niere. Deutsches. Arch. f. klin. Med., 1913, 110, 101.

9. Smirnow, A. E. v., Ueber die Nervenendigungen in den Nieren der Säugetiere. Anat. Anz., 1901, 19, 347.

10. Cushny, A. R., The secretion of urine. Longmans, Green and Co., London, 1926, 2nd ed.
11. Bernard, C., Leçons sur les propriétés physiologiques et les altérations pathologiques des liquides de l'organisme. Baillière, Paris, 1859.

12. Eckhard, C., Untersuchungen über Hydrurie. Beitr. z. Anat. u. Physiol., 1867, 4, 155; Ibid. 1870, 5, $149 ; 1871,6,53$.

13. Klecki, C. V., Ueber die Ausscheidung von Bacterien durch die Niere und die Beinflussung dieses Processes durch die Diurese. Arch. f. exper. Path. u. Pharmakol., 1897, 39, 173.

14. Grek, J., Über den Einfluss der Durchtrennung und Reizung des nervus splanchnicus auf die Ausscheidung der Chloride durch die Nieren und das Auftreten von Glykosurie bei Reizung des nervus splanchnicus. Arch. f. exper. Path. u. Pharmakol., 1912, 68, 305.

15. Rohde, E., and Ellinger, P., Über die Funktion der Nierennerven. Zentralbl. f. Physiol., 1913, 27, 12.

16. Asher, L., and Pearce, R. G., I)ie sekretorische Innervation der Niere. Ztschr. f. Biol., 1913, 63, 83.

17. Jungmann, P., and Meyer, E., Experimentelle Untersuchungen über die Abhängigkeit der Nierenfunktion von Nervensystem. Arch. f. exper. Path. u. Pharmakol., 1913, 73, 49.

18. Marshall, E. K., Jr., and Crane, M. M., Studies on the nervous control of the kidney in relation to diuresis and urinary secretion. VI. The effect of unilateral section of the splanchnic nerve on the elimination of certain substances of the kidney. Am. J. Physiol., 1922, 62, 330.

19. Bieter, R. N., Action of splanchnic nerves on glomerular blood flow and mechanism of reflex anuria in frog's kidney. Proc. Soc. Exper. Biol. and Med., 1928-1929, 26, 792.

20. Burton-Opitz, R., and Lucas, D. R., Über die Blutversorgung der Niere. I. Der Einfluss der Erhöhung des Druckes in den Harnwegen sowie der Reizung und Durchschneidung der den Plexus renalis bildenden Nervenfasern. Arch. f. Physiol., 1908, 123, 553. II. Der Einfluss der rechten Nervus splanchnicus auf die Blutfülle des linken Organs. Ibid, 1908, 125, 221.

21. Carrel, A., and Guthrie, C. C., Successful transplantation of both kidneys from a dog into a bitch with removal of both normal kidneys from the latter. Science, 1906, 23, 394.

22. Carrel, A., Results of the transplantation of blood vessels, organs and limbs. J. A. M. A., 1908, 51, 1662.

23. Dederer, C., Studies in the transplantation of whole organs. I. Autotransplant of the left kidney to the neck with right nephrectomy in the dog. J. A. M. A., 1918, 70, 6 .

24. Dederer, C., Successful experimental homotransplantation of the kidney and the ovary. Surg. Gynec. and Obst., 1920, 31, 45.

25. Ibuka, K., Function of the autogenous kidney transplant. Am. J. M. Sc., 1926, 171, 407. 
26. Holloway, J. K., The effect of diuretics on transplanted kidneys. J. Urol., 1926, 15, 111.

27. Lobenhoffer, W., Funktionsprüfungen an transplantierten Nieren. Mitt. a. d. Grenzgeb. d. Med. u. Chir., 1913, 26, 197.

28. Fee, A. R., Studies on water diuresis. II. The excretion of urine after hypophysectomy and decerebration. J. Physiol., 1929, 68, 305.

29. Bayliss, L. E., and Fee, A. R., Studies on water diuresis. III. A comparison of the excretion of urine by innervated and denervated kidneys perfused with the heart-lung preparation. J. Physiol., 1930, 69, 135.

30. Stierlin and Verriotis, Über den Einfluss des Nervensystem auf die Funktion der Niere. Deutsche Ztschr. f. Chir., 1920, 152, 37.

31. Caldwell, J. M., Marx, H., and Rowntree, L. G., Renal function after bilateral denervation of the kidney in normal dogs. J. Urol., 1931, 25, 351.

32. Quinby, W. C., The function of the kidney when deprived of its nerves. J. Exper. Med., 1916, 23, 535.

33. Marshall, E. K., Jr., and Kolls, A. C., Studies on the nervous control of the kidney in relation to diuresis and urinary secretion. I. The effect of unilateral excisions of the adrenal, section of the splanchnic nerve and section of the renal nerves on the secretion of the kidney. Am. J. Physiol., 1919, 49, 302 ; II. A comparison of the changes caused by unilateral splanchnotomy with those caused by unilateral compression of the renal artery. Ibid, 1919, 49, 317.

34. Milliken, L. F., and Karr, W. G., The influence of the nerves on kidney function in relation to the problem of renal sympathectomy. J. Urol., 1925, $13,1$.

35. Kusakari, H., Über die Beziehungen der Nierenfunktion zum vegetativen Nervensystem. I. Einfluss der Durchschneidung und Reizung der Splanchnici und des Vagus auf die Harnabsonderung. Tohoku J. Exper. Med., 1930, 16, 509. II. Einfluss der Splanchnici und des Vagus auf die Farbstoffausscheidung. Ibid, 1930, 16, 546.

36. Hecht, R., Studies in renal denervation. IV. Proc. Soc. Exper. Biol. and Med., 1931-32, 29, 973.

37. Milles, G., Müller, E. F., and Petersen, W. F., Studies in renal denervation. I. Roentgenographic demonstration of vascular alteration. Proc. Soc. Exper. Biol. and Med., 1930-31, 28, 354.

38. Rhoads, C. P., Van Slyke, D. D., Hiller, Alma and Alving, A. S., The effects of novocainization and total section of the nerves of the renal pedicle on renal blood flow and function. Am. J. Physiol., 1934, 110, 392.

39. Müller, E. F., and Petersen, W. F., Ueber den Anteil des vegetativen Nervensystems an den Infectionsschäden der Nierengefässe. Verhandl. d. deutsch. Gesellsch. f. inn. Med., 1932, 44, 419.

40. Milles, G., Müller, E. F., and Petersen, W. F., Renal denervation. The effect of snake venom and chill- ing on the renal vascularization. Arch. Path., 1932, 13, 233.

41. Cohnheim, J., and Roy, C. S., Untersuchungen über die Circulation in den Nieren. Virch. Arch. f. path. Anat., 1883, 92, 424.

42. Wertheimer, E., De l'influence de la réfrigeration de la peau sur la circulation du rein. Arch. d. phys. norm. et. path., 1894, 6 (series 5), 308.

43. Hecht, R., Studies in renal denervation. III. Bacterial embolism in the normal and denervated kidney. Proc. Soc. Exper. Biol. and Med., 1931-32, 29, 212.

44. Milles, G., and Nedzel, A. J., Permeability of normal and denervated kidney to bacteria. Proc. Soc. Exper. Biol. and Med., 1931-32, 29, 976.

45. Richards, A. N., and Schmidt, C. F., A description of the glomerular circulation in the frog's kidney and observations concerning the action of adrenalin and various other substances upon it. Am. J. Physiol., 1924, 71, 178.

46. Müller, E. F., Petersen, W. F., and Rieder, W., Functional pathology of the denervated kidney. Proc. Soc. Exper. Biol. and Med., 1929-30, 27, 739.

47. Moriconi, L., La decapsulazione renale e la simpatectomia periarteriosa nelle nefriti suppurative. Clin. Chir. (Milan), 1934 37, 637.

48. Page, I. H., The relationship of the extrinsic renal nerves to the origin of nephritic hypertension. Am. J. Physiol., 1935, 112, 166.

49. Goldblatt, H., Lynch, J., Hanzal, R. F., and Summerville, W. W., Studies on experimental hypertension. I. The production of persistent elevation of systolic blood pressure by means of renal ischemia. J. Exper. Med., 1934, 59, 347.

50. Wiedhopf, O., Experimentelle Untersuchungen über die Beinflussung der Nierenfunktion durch paravertebrale Ausschaltung der Nierensegmente. Beitr. z. klin. Chir., 1927, 141, 171.

51. Lurz, L., and Röhrich, H., Einfluss der paravertebralen Anästhesie auf die Nierensekretion. Beitr. z. klin. Chir., 1929, 147, 639.

52. Haslinger, K., Zur Therapie der reflektorischen Anurie. Ztschr. f. Urol., 1927, 21, 174.

53. Neuwirt, K., Ein Beitrag zur Therapie der Reflexanurie. Ztschr. f. Urol. Chir., 1922, 11, 75.

54. Havlicek, H., Die Leitungsunterbrechung der Splanchnicusbahn zur Behebung der Nierengefsässabdrosselung. Zentralbl., f. inn. Med., 1925, 46, 465.

55. Papin, E., De l'énervation des reins dans les affections douloureuses de cet organe. Arch. francobelges de chir., 1923, 26, 615.

56. Legueu, F., and Flandrin, P., Enervation du rein. Presse méd., 1923, 31, 741.

57. Harris, S. H., and Harris, R. G. S., Renal sympathetico-tonus, renal pain and renal sympathectomy. Brit. J. Urol., 1930, 2, 367.

58. Herbst, W. P., Pyeloscopic and urographic study before and after renal sympathectomy. J. A. M. A., 1932, 99, 2004. 
59. Hess, E., Renal sympathectomy. J. Urol., 1928, 20, 333.

60. Stone, E., Renal sympathectomy report of two cases including one fatality. New England J. Med., 1934, 210, 1257.

61. Rieder, W., Erfolgreiche Versuche, urämische Zustände operativ zu behandeln. Arch. f. klin. Chir., 1933, 177, 618.

62. Volhard, F., Die doppelseitigen hämatogenen Nierenerkrankungen. Springer, Berlin, 1931, 2nd ed.

63. Page, I. H., and Heuer, G. J., The effect of renal denervation on the level of arterial blood pressure and renal function in essential hypertension. J. Clin. Invest., 1935, 14, 27.

64. Van Slyke, D. D., Stillman, Edgar, Möller, E., Ehrich, E., McIntosh, J. F., Leiter, L., MacKay, E. M., Hannon, R. R., Moore, N. S., and Johnston, C., Observations on the courses of different types of Bright's disease, and on the resultant changes in renal anatomy. Medicine, 1930, 9, 257.

65. Mфller, E., McIntosh, J. F., and Van Slyke, D. D., Studies of urea excretion. IV. Relationship between urine volume and rate of urea excretion by patients with Bright's disease. J. Clin. Invest., 1928, 6, 485.

66. Van Slyke, D. D., Rhoads, C. P., Hiller, Alma, and Alving, Alf, The relationship of the urea clearance to the renal blood flow. Am. J. Physiol., 1934, 110, 387.
67. Addis, T., and Shevky, M. C., A test of the capacity of the kidney to produce a urine of high specific gravity. Arch. Int. Med., 1922, 30, 559.

68. Alving, Alf S., and Van Slyke, D. D., The significance of concentration and dilution tests in Bright's disease. J. Clin. Invest., 1934, 13, 969.

69. Lashmet, F. H., and Newburgh, L. H., An improved concentration test of renal function. J. A. M. A., 1932, 99, 1396.

70. Shevky, M. C., and Stafford, D. D., A clinical method for the estimation of protein in urine and other body fluids. Arch. Int. Med., 1923, 32, 222.

71. Addis, T., The number of formed elements in the urinary sediment of normal individuals. J. Clin. Invest., 1926, 2, 409.

72. Howe, P. E., The determination of proteins in blooda micro-method. J. Biol. Chem., 1921, 49, 109.

73. Kirk, E., Page, I. H., and Van Slyke, D. D., Gasometric microdetermination of lipids in plasma, blood cells, and tissues. J. Biol. Chem., 1934, 106, 203.

74. Kirk, E., The ability of nephritic patients to deaminize and form urea from ingested glycine. J. Clin. Invest., 1935, 14, 136.

75. Page, I. H., The effect on renal efficiency of lowering arterial blood pressure in cases of essential hypertension and nephritis. J. Clin. Invest., 1934, 13, 909. 